\title{
Seleksi Padi dengan Kandungan Amilosa Sedang Menggunakan Marka Molekuler dan Pengujian Fenotipik
}

\section{Selection of Rice with Medium Amylose Content by Using Molecular Marker and Phenotypic Assessment}

\author{
Whitea Yasmine Slamet ${ }^{1}$, Anita Rachmasari S.W.', Santika Sari ${ }^{3}$ dan Nono Carsono ${ }^{3}$ \\ 'Mahasiswa Program Pasca Sarjana Pemuliaan Tanaman, Universitas Padjadjaran \\ ${ }^{2}$ Mahasiswa Program Sarjana Pemuliaan Tanaman, Universitas Padjadjaran \\ ${ }^{3}$ Dosen Departemen Budidaya Pertanian, Fakultas Pertanian, Universitas Padjadjaran \\ Jl. Raya Bandung-Sumedang KM 21, Jatinangor 45363
}

\begin{abstract}
Rice with medium amylose content is a special type of rice that highly demanded by the people in Asia and world. The purpose of this study was to obtain individual F7 progeny (derived from a cross between Sintanur x PTB33 and Pandanwangi x PTB33) with medium amylose content. The materials used were spectrophotometer with wave lenght $625 \mathrm{~nm}$, meanwhile molecular markers applied were RM190, SSIIa and Wx. The results of this study showed that SP73-3-1-7 have most plant with medium amylose content based on molecular and phenotypic marker. The combination of both tests provides more accurate in selecting physicochemical trait in rice.
\end{abstract}

Keywords: Rice, Molecular marker, Amylose Content, Spektrophotometer

\begin{abstract}
Abstrak: Padi dengan kandungan amilosa sedang sangat diminati oleh masyarakat Asia dan Dunia. Tujuan dari penelitian ini adalah untuk memperoleh individu keturunan $\mathrm{F}_{7}$ (yang berasal dari hasil persilangan Sintanur x PTB33 dan Pandanwangi x PTB33) dengan kandungan amilosa sedang. Alat yang digunakan untuk analisis kandungan amilosa yaitu spektrofotometer dengan panjang gelombang $625 \mathrm{~nm}$, sedangkan marka molekuler menggunakan marka RM190, SSIIa dan Wx. Hasil dari penelitian ini menunjukkan bahwa SP73-3-1-7 memiliki jumlah tanaman paling banyak yang mengandung amilosa yang sedang berdasarkan marka molekuler dan fenotipik. Kombinasi kedua pengujian ini akurat dalam menyeleksi karakter fisikokimia padi.
\end{abstract}

Kata kunci: Padi, Marka molekuler, Kandungan amilosa, Spektrofotometer

\section{Pendahuluan}

Padi dengan kandungan amilosa sedang sangat diminati petani karena nilai jual yang tinggi di pasar lokal maupun internasional. Sehingga, penting untuk dikembangkan metode pemuliaan padi dengan kandungan amilosa sedang yang sesuai untuk memenuhi permintaan konsumen dan meningkatkan pendapatan petani. Menurut Hsu et al. (2014), kandungan amilosa dikendalikan secara kuantitatif dengan gen mayor $\mathrm{Wx}$ yang memiliki enzim aktif memengaruhi produksi granule-bound starch synthase (GBSS). Ekspres dari gen ini dapat diamati melalui analisis fenotipik dan marka molekuler. Kedua metode tersebut bisa membedakan tingkat kandungan amilosa padi. Kombinasi kedua pengujian tersebut dapat memberikan informasi yang lebih akurat mengenai kandungan amilosa padi.

Analisis kandungan amilosa padi dapat dideteksi menggunakan Spektrofotmeter dengan panjang gelombang $625 \mathrm{~nm}$ dan dengan marka molekuler spesifik (Purdianty, A. 2016). Marka ini terkait erat dengan gen $\mathrm{Wx}$ yang mengendalikan ekspresi karakter amilosa. Gen Wx terletak pada kromosom 6 (Hsu et al., 2014). Penelitian ini dilakukan dengan menggunakan keturunan $\mathrm{F}_{7}$ dari persilangan Sintanur x PTB-33(SP) dan Pandanwangi x PTB33(PP). Sintanur dan Pandanwangi merupakan varietas lokal Indonesia dengan kandungan amilosa sedang (18-24\%) (Balai Besar Penelitian Tanaman Padi, 2009). PTB-33 merupakan kultivar hasil introduksi dari India yang memiliki kandungan amilosa tinggi dan tahan wereng coklat (Balai Besar Penelitian Tanaman Padi, 2012). Tujuan dari penelitian ini adalah merakit genotip baru yang memiliki kandungan amilosa sedang dan tahan wereng. Pada seleksi berbasis marka molekuler $\mathrm{F}_{2}$ untuk tahan wereng coklat telah dilakukan, namun 
seleksi kandungan amilosa sedang belum dilakukan. Oleh karena itu, sebagai upaya yang efektif untuk mencapai target, evaluasi kandungan amilosa sedang untuk pengujian $\mathrm{F}_{7}$ diperlukan melalui analisis fenotipik menggunakan spektrofotometer dengan panjang gelombang $625 \mathrm{~nm}$ dan marka molekuler.

\section{Bahan dan Metode}

\section{Bahan tanaman}

Empat belas genotip keturunan $\mathrm{F}_{6}$ hasil persilangan Sintanur x PTB-33(SP) dan Pandanwangi $\mathrm{x}$ PTB-33(PP) dievaluasi. Masing-masing genotip terdiri dari empat puluh tanaman, sehingga jumlah total sampel 560 tanaman. Semua sampel sudah diidentifikasi tahan wereng coklat berdasarkan marka molekuler pada keturunan $\mathrm{F}_{2}$. Sampel beras dikumpulkan untuk pengujian fenotipik, sedangkan marka molekuler menggunakan sampel daun.

\section{Analisis kandungan amilosa padi (BB Padi Sukamandi, 2017)}

Analisis kandungan amilosa dilakukan menggunakan spektrofotometer dengan panjang gelombang $625 \mathrm{~nm}$. Beras digerus hingga menjadi tepung, ditimbang sebanyak $1 \mathrm{mg}$, dimasukan dalam mikrotube lalu ditambahkan $10 \mu$ etanol 95\% dan $90 \mu$ larutan $\mathrm{NaOH} 1 \mathrm{~N}$. Kemudian diinkubasi pada suhu $95^{\circ} \mathrm{C}$ selama 10 menit lalu diencerkan dengan aquades sampai volume $1 \mathrm{ml}$. Diambil sebanyak 50 $\mu$ l larutan, kemudian dimasukkan dalam microtube 2 $\mathrm{ml}$, ditambahkan $20 \mu \mathrm{l}$ iodine dan $10 \mu \mathrm{l}$ asam asetat 1 N. Selanjutnya diencerkan kembali dengan akuades sampai $1 \mathrm{ml}$, larutan tersebut dikocok lalu didiamkan selama 20 menit. Kemudian dianalisis menggunakan spektrofotometer $625 \mathrm{~nm}$.

\section{Ekstraksi DNA dan amplifikasi PCR}

Ekstrasi DNA dari daun muda dilakukan dengan metode CTAB (Doyle dan Doyle, 1987) dengan sedikit modifikasi. Kualitas DNA dianalisis dengan menggunakan elektroforesis. Elektroforesis kualitas DNA dilakukan menggunakan $2 \%$ gel agarose yang dilarutkan dalam $100 \mathrm{ml}$ TBE 0,5x. Proses elektroforesis dilakukan pada tegangan dan durasi tertentu sesuai dengan primer, kemudian direndam dalam larutan EtBr (ethidium bromide) selama 30 menit dan dalam air destilasi selama 10 menit.

Identifikasi gen $\mathrm{Wx}$ dilakukan dengan menggunakan primer spesifik. PCR dilakukan dengan menggunakan $1 \mu \mathrm{l}$ DNA genom $20 \mu^{-1}, 5 \mu \mathrm{l}$ KAPPA, $1 \mu \mathrm{l}$ masing-masing primer (RM190, Wx dan SSIIA) pada volum total $10 \mu \mathrm{l}$. Produk PCR dianalisis menggunakan elektroforesis (ethidium bromide (0,5 ug mL-1), 2.0\% gel agaros dan $100 \mathrm{bp}$ ladder).

\section{Hasil dan Pembahasan}

Dalam penelitian ini, kandungan amilosa padi telah dianalisis di laboratorium. Hasil penelitian menunjukkan bahwa kandungan amilosa padi dapat dideteksi dengan Spektrofotometer dengan panjang gelombang $625 \mathrm{~nm}$ dan amplifikasi PCR spesifik. Contoh visualisasi pengujian kandungan amilosa sedang menggunakan marka molekuler dengan marka RM190 (Gambar 1), SSIIa (Gambar 2), Wx (Gambar 3) dapat dilihat dibawah ini,

Pada penelitian ini, setiap genotip uji terdiri dari 40 tanaman sehingga persentase dilakukan per 40 tanaman. Tercatat jumlah tanaman yang memiliki amilosa sedang per genotip (Tabel 1).
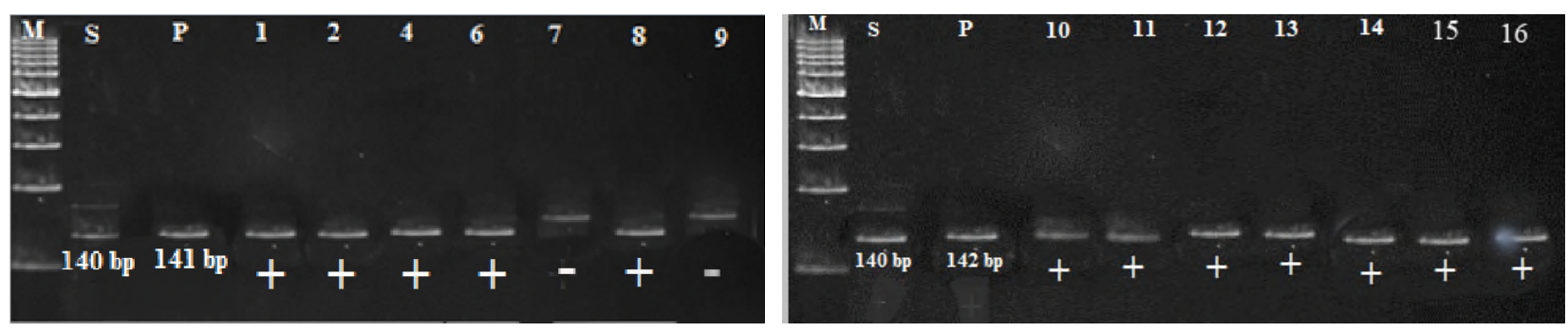

Gambar 1. Visualisasi gel elektroforesis untuk karakter kandungan amilosa berdasarkan primer RM190. Ket : M= ladder 100 bp; $\mathrm{S}=$ Sintanur; P = Pandanwangi; Genotip \#1- \#14 = genotip uji; $(+)=$ pola pita DNA sesuai dengan target yang diinginkan (kandungan amilosa rendah-sedang); $(-)=$ pola pita DNA tidak sesuai dengan target yang diinginkan (kandungan amilosa tinggi). 

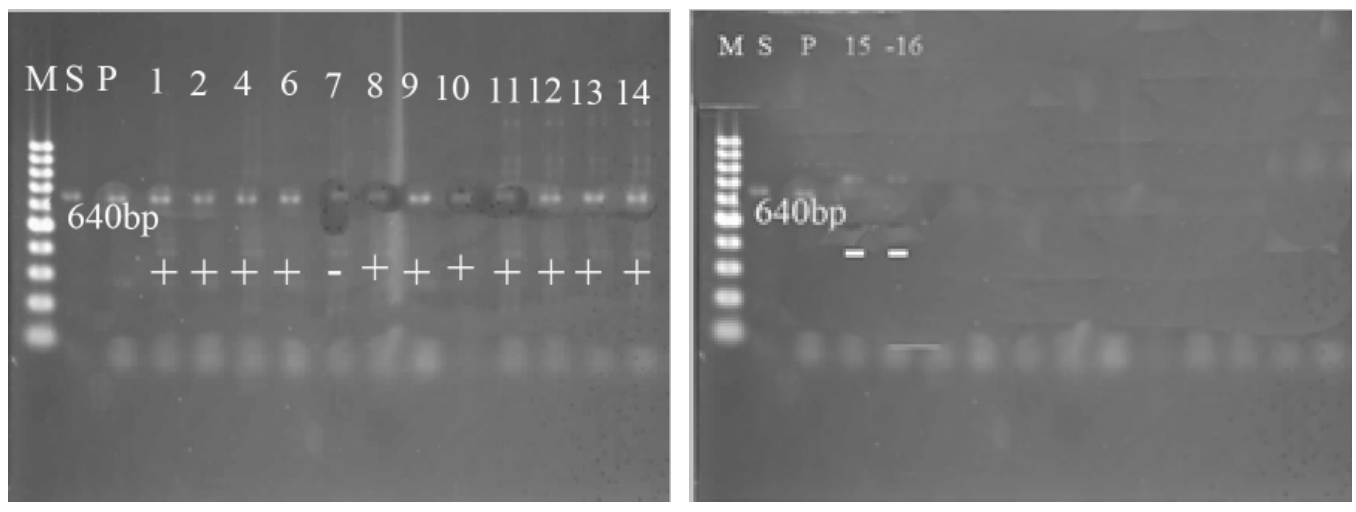

Gambar 2. Visualisasi gel elektroforesis untuk karakter kandungan amilosa berdasarkan primer SSIIa. Ket : M= ladder 100 bp; S = Sintanur; P = Pandanwangi; Genotip \#1- \#14 = genotip uji $(+)=$ pola pita DNA sesuai dengan target yang diinginkan (kandungan amilosa rendah-sedang); $(-)=$ pola pita DNA tidak sesuai dengan target yang diinginkan (kandungan amilosa tinggi).
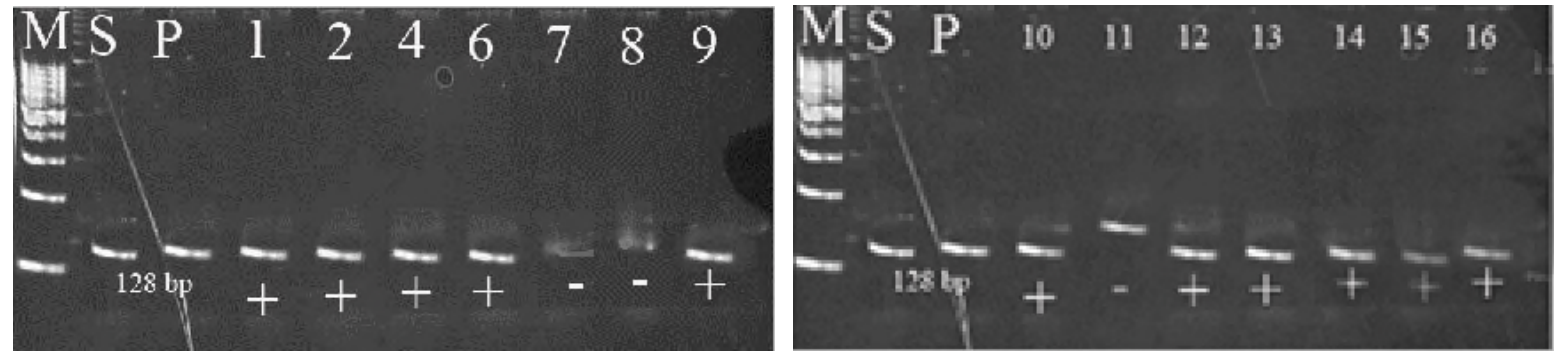

Gambar 3. Visualisasi gel elektroforesis untuk karakter amilosa berdasarkan primer Wx. Ket : M= ladder 100 bp; $\mathrm{S}=$ Sintanur; P = Pandanwangi; Genotip \#1- \#14 = genotip uji; $(+)=$ pola pita DNA sesuai dengan target yang diinginkan (kandungan amilosa rendah-sedang); $(-)=$ pola pita DNA tidak sesuai dengan target yang diinginkan (kandungan amilosa tinggi).

Tabel 1. Perangkingan genotip padi yang memiliki kandungan amilosa sedang terbanyak dengan pengujian menggunakan spektrofotometer dan marka molekuler

\begin{tabular}{|c|c|c|c|c|c|}
\hline No. & Genotip & Spektrofotometer & $\begin{array}{c}\text { Persentase menggunakan } \\
\text { spektrofotometer }\end{array}$ & Marka molekuler & $\begin{array}{c}\text { Persentase dengan marka } \\
\text { molekuler }\end{array}$ \\
\hline 1 & SP73-3-1-7 & 22 tanaman & $55 \%(22 / 40$ tanaman $)$ & 35 tanaman & $87,5 \%$ (35/40 tanaman) \\
\hline 2 & SP73-3-1-33 & 19 tanaman & $47,5 \%$ (19/40 tanaman) & 32 tanaman & $80 \%(32 / 40$ tanaman $)$ \\
\hline 3 & SP73-3-1-27 & 16 tanaman & $40 \%(16 / 40$ tanaman $)$ & 26 tanaman & $65 \%$ (26/40 tanaman) \\
\hline 4 & SP73-3-1-29 & 20 tanaman & $50 \%(20 / 40$ tanaman $)$ & 22 tanaman & $55 \%$ (22/40 tanaman) \\
\hline 5 & SP73-3-1-37 & 14 tanaman & $35 \%(14 / 40$ tanaman $)$ & 22 tanaman & $55 \%$ (22/40 tanaman) \\
\hline 6 & $\mathrm{PP}_{48-3-1-6}$ & 18 tanaman & $45 \%(18 / 40$ tanaman $)$ & 21 tanaman & $52,5 \%$ (21/40 tanaman) \\
\hline 7 & SP $46-4-1-44$ & 10 tanaman & $25 \%(10 / 40$ tanaman $)$ & 18 tanaman & $45 \%(18 / 40$ tanaman $)$ \\
\hline 8 & SP87-24-1-28 & 7 tanaman & $17,5 \%(7 / 40$ tanaman $)$ & 13 tanaman & $32,5 \%$ (13/40 tanaman) \\
\hline 9 & SP73-3-1-2 & 6 tanaman & $15 \%(6 / 40$ tanaman $)$ & 13 tanaman & $32,5 \%$ (13/40 tanaman) \\
\hline 10 & $\mathrm{SP} 87-1-1-7$ & 6 tanaman & $15 \%(6 / 40$ tanaman $)$ & 12 tanaman & $30 \%$ (12/40 tanaman) \\
\hline 11 & $\mathrm{SP} 73-3-1-5$ & 5 tanaman & $12,5 \%(5 / 40$ tanaman $)$ & 12 tanaman & $30 \%$ (12/40 tanaman) \\
\hline 12 & SP73-3-1-8 & 15 tanaman & $37,5 \%$ (15/40 tanaman) & 12 tanaman & $30 \%$ (12/40 tanaman) \\
\hline 13 & SP73-3-1-15 & 5 tanaman & $12,5 \%$ (5/40 tanaman) & 12 tanaman & $30 \%$ (12/40 tanaman) \\
\hline 14 & SP73-1-1-17 & 2 tanaman & $5 \%(2 / 40$ tanaman $)$ & 10 tanaman & $25 \%$ (10/40 tanaman) \\
\hline
\end{tabular}


Pada penelitian ini, SP73-3-1-7 terseleksi menggunakan spektrofotometer dengan panjang gelombang $625 \mathrm{~nm}$ dan berdasarkan marka molekuler memiliki jumlah tanaman dengan kandungan amilosa sedang terbanyak. Sehingga SP73-3-1-7 terseleksi berdasarkan kedua pengujian tersebut.

Tanaman yang terseleksi berdasarkan spektrofotometer, tetapi tidak terseleksi berdasarkan marka molekuler, diduga karena ada gen lain yang mengendalikan amilosa. Menurut Tian et al. (2009) bahwa selain gen $\mathrm{Wx}$ terdapat gen SSIII-2, SSI, AGPlar dan PUL yang mengendalikan kandungan amilosa juga. Sehingga tanaman tersebut terdeteksi dengan Spektrofotometer, namun tidak dengan marka molekuler. Genotip yang dipilih berdasarkan marka molekuler namun tidak dipilih berdasarkan Spektrofotometer karena kandungan amilosa sangat rendah pada tanaman tersebut sehingga tidak dapat ditangkap oleh Spektrofotometer.

\section{Kesimpulan}

Lima ratus enam puluh tanaman yang merupakan generasi $\mathrm{F}_{7}$ hasil persilangan Sintanur $\mathrm{x}$ PTB 33(SP) dan Pandanwangi x PTB 33(PP) telah dianalisis dalam penelitian ini. SP73-3-1-7 memiliki paling banyak genotip dengan kandungan amilosa sedang berdasarkan analisis menggunakan spektrofotometer dan marka molekuler. Karena pada $\mathrm{F}_{2}$ tanaman ini telah dievaluasi secara marka molekuler untuk tahan wereng coklat, sehingga tanaman terseleksi pada $\mathrm{F}_{7}$ ini memiliki dua karakter penting: tahan hama wereng coklat dan memiliki kandungan amilosa sedang.

\section{Ucapan Terima Kasih}

Penulis ingin mengucapkan terima kasih kepada Kemenristek Dikti atas pendanaan penelitian ini melalui Hibah PUPTN yang diberikan kepada Nono Carsono.

\section{Daftar Pustaka}

Balai Besar Penelitian Tanaman Padi. 2009. Deskripsi Varietas Padi. BB Padi, Departemen Pertanian

Balai Besar Penelitian Tanaman Padi. 2012. Melalui http://bbpadi.litbang.deptan.go.id/.

Balai Besar Penelitian Tanaman Padi. 2012. Analisis Amilosa. Sukamandi

Hsu, Y.-C., M.-C. Tseng, Y.-P. Wu, M.-Y. Lin, F. Wei, K.-K. Hwu, Y. Hsing, and Y.-R. Lin. 2014. Genetic factors responsible for eating and cooking qualities of rice grains in a recombinant inbred population of an inter-subspecific cross. Mol. Breed. 34: 655-673.

Purdianty, A. 2016. Seleksi karakter aroma menggunakan marka molekuler dan uji sensori, seleksi warna biji, serta identifikasi karakter kadar amilosa dan komponen hasil pada padi generasi F3 terseleksi. Univ. Padjadjaran: 8-34.

Tian, Z., Q. Qian, Q. Liu, M. Yan, X. Liu, C. Yan, G. Liu, Z. Gao, S. Tang, D. Zeng, Y. Wan, J. Yu, M. Gu, J. Li. 2009. Allelic diversities in rice starch biosynthesis lead to a diverse array of rice eating and cooking qualities. www.pnas.org 